\title{
HUBUNGAN JENIS KELAMIN TERHADAP KEBERSIHAN RONGGA MULUT ANAK PANTI ASUHAN
}

Diana Setya Ningsih*

\begin{tabular}{|c|c|}
\hline & ABSTRACT \\
\hline $\begin{array}{l}\text { Keywords: } \\
\text { OHIS, gender, child }\end{array}$ & $\begin{array}{l}\text { Background: Dental health of child is a reflection of a healthy life of their future. } \\
\text { It is strongly influenced by the child's oral hygiene which can be seen from } \\
\text { the index of OHIS (oral hygiene index simplified). The level of oral hygiene in } \\
\text { general is influenced by their gender and parents. Purpose: This study aimed } \\
\text { to assess the effect of gender on children's oral hygiene at the orphanage. }\end{array}$ \\
\hline & $\begin{array}{l}\text { Method: This research was conducted at the orphanage Al Ishlah Al Aziziyah } \\
\text { Banda Aceh with randomly selected subject by quota sampling technique. The } \\
\text { subject of this study was } 76 \text { people (boy }=38 \text { people and girl }=38 \text { people). } \\
\text { Subjects were applied by disclosing solution for } 5 \text { minutes and then recorded } \\
\text { a score of debris and calculus using the index proposed by Greene and } \\
\text { Vermillion. the value of debris and calculus were summed to obtain the index } \\
\text { of OHIS. Result: The results showed the level of dental hygiene of the girls are } \\
\text { much better than the level of oral hygiene of the boys }(p<0.05) \text {. Conclusion: It } \\
\text { was concluded that gender affects oral health of children. }\end{array}$ \\
\hline
\end{tabular}

\section{PENDAHULUAN}

Anak merupakan generasi muda yang menjadi cikal bakal pemimpin di masa akan datang. Definisi anak berdasarkan Konvensi Hak Anak (KHA) adalah adalah manusia yang berusia dibawah 18 tahun kecuali berdasarkan undang-undang sudah mencapai kedawasaan yang lebih cepat ${ }^{1}$. Anak dapat dikelompokkan menjadi 3 kategori yaitu bayi (0-1 tahun), usia bermain/olddler (1-2,5 tahun), pra sekolah (2,55 tahun), usia sekolah (5-11 tahun), remaja (11-18 tahun) ${ }^{2}$. Anak harus dipersiapkan sedini mungkin untuk menghadapi kehidupan mereka termasuk kesehatan gigi dan mulut.

Kesehatan gigi dan mulut anak sangat dipengaruhi oleh pemeliharaan mereka. Berdasarkan hasil RISKESDAS 2013 menunjukkan hanya 2,2 \% anak di daerah aceh yang benar merawat gigi dan mulut mereka yang ditinjau dari kemampuan menyikat gigi dan mulut yang baik dan benar. Selain itu, hanya 5,9-7 anak-anak di Aceh yang mencari pelayanan kesehatan gigi dan mulut ${ }^{3}$. Keterbatasan ini, mempermudah terbentuknya plak dan kalkulus sehingga akan merusak gigi dan jaringan pendukung gigi. Hal ini sesuai dengan penelitian Anitasari yang menyatakan ada hubungan perilaku membersihankan gigi dan mulut terhadap kebersihan gigi dan mulut anak $^{4}$.

Beberapa penelitian juga mengungkapkan bahwa kebersihan gigi dan mulut anak juga dipengaruhi oleh jenis kelamin. Hal ini sesuai dengan penelitian yang dilakukan oleh Zetu, Ogunsile dan Mutawa yang menyatakan ada pengaruh jenis kelamin terhadap kebersihan gigi dan mulut ${ }^{5-7}$. Anakanak yang berjenis kelamin perempuan lebih memiliki kesehatan gigi dan mulut yang jauh lebih baik. Namun, penelitian Indrawati menunjukkan kebersihan gigi dan mulut anak perempuan sedikit lebih tinggi namun tidak signifikan dibandingkan anak laki-laki ${ }^{8}$.

Selain itu, edukasi yang adekuat dari orang tua terutama ibu juga dapat mempengaruhi kebersihan gigi anak. Hal ini sesuai penelitian Saeid yang menyatakan kebiasaan orang tua dalam menjaga kebersihan gigi dan mulut serta tingkat kesadaran orang

* Fakultas Kedokteran Gigi Universitas Syiah Kuala -Darussalam Banda Aceh

Korespondensi: dee_aceh@yahoo.co.id 
tua untuk mengontrol keadaan gigi anak mereka dapat mempengaruhi kebersihan gigi dan anak mereka ${ }^{9}$. Kondisi ini ideal ini sulit ditemui oleh beberapa anak terutama anakanak yang tinggal di panti asuhan. Anak-anak panti asuhan sulit mendapatkan perhatian khusus / spesial dari orang tua mereka disebabkan oleh ketidakmampuan orang tua untuk merawat anak mereka secara utuh. Oleh sebab itu, penelitian ini bertujuan untuk menilai kebersihan gigi anak panti asuhan berdasarkan jenis kelamin (perempuan/laki-laki). Kebersihan gigi anak dapat dinilai melalui standar penilaian kebersihan gigi dan mulut yaitu Oral Hygiene Index Simplified (OHIS).

\section{METODE PENELITIAN}

Penelitian ini merupakan penelitian deskriptif dengan pendekatan cross sectional. Penelitian ini dilakukan di panti asuhan Al Ishlah Al Aziziyah Banda Aceh dan subjek penelitian dipilih menggunakan teknik quota sampling sehingga subjek yang ditentukan pada penelitian ini adalah 78 orang (lakilaki $=38$ orang dan perempuan 38 orang). Teknik pengumpulan data ini menggunakan borang OHIS dan pemeriksaan OHIS pada subjek. Sebelumnya seluruh subjek dioleskan disclossing solution untuk melihat debris dan kalkulus yang tertinggal pada gigi mereka. Gambaran yang terlihat pada gigi mereka dicatat sesuai dengan indek Debris (ID) dan indek Kalkulus (IK). (Gambar 1)

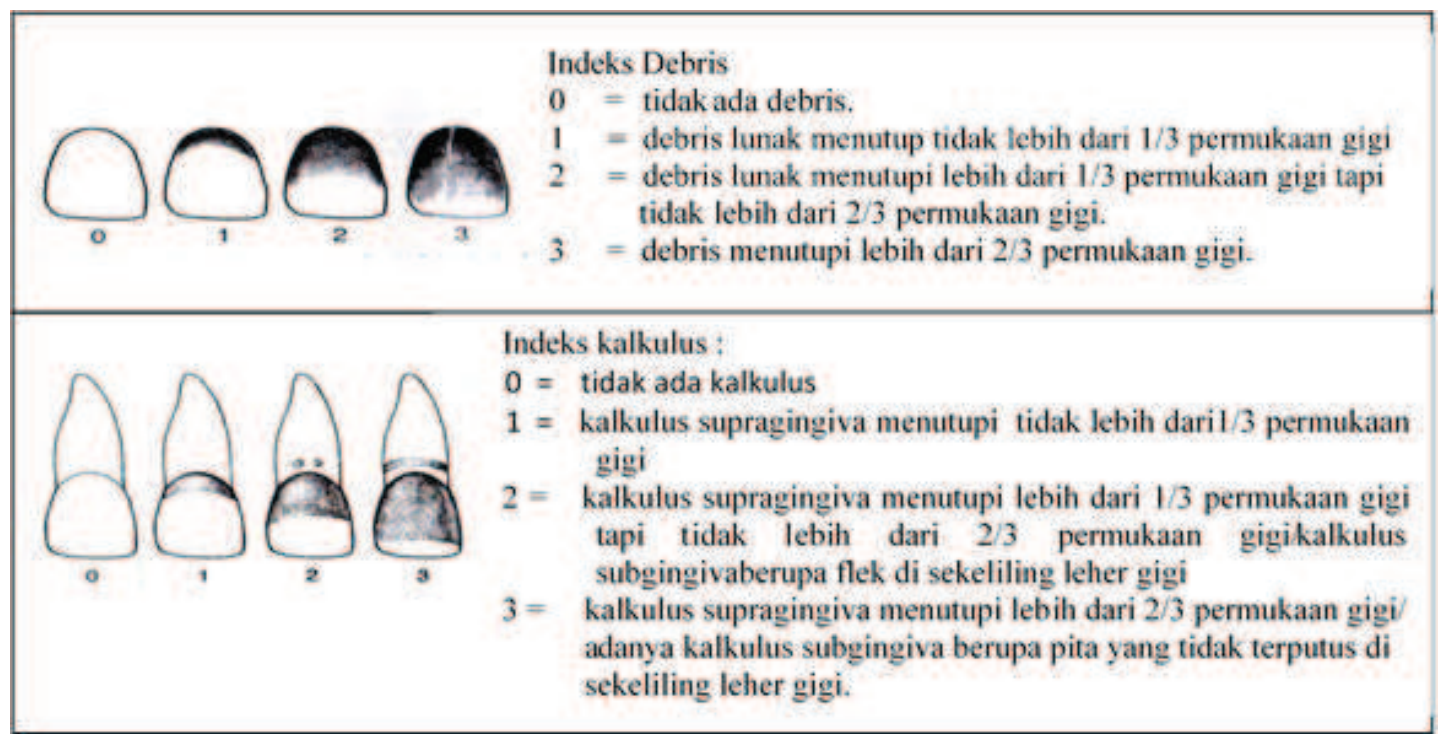

Gambar 1. Indeks Debris (A) dan Indeks Kalkulus (B)

$\begin{array}{clcr}\text { Indek } & \text { yang } & \text { diperoleh } & \text { kemudian } \\ \text { dijumlahkan } & \text { dan dikategorikan } & \text { kembali }\end{array}$ berdasarkan Indeks OHIS Greene and Vermillion dimana kategori baik $=0,1-1,2$, sedang $=1,3-3,0$ dan buruk $=3,1-6,0.7,8$ Data yang diperoleh kemudian diuji menggunakan uji statistik chi square dengan nilai $p<0,05$ untuk melihat perbedaan kebersihan gigi dan mulut pada anak-anak panti asuhan.

\section{HASIL PENELITIAN}

Hasil penelitian ini menggambarkan kondisi rongga mulut anak-anak terutama anakanak yang ada di panti asuhan yang berusia antara 12-18 tahun. Data seberan distribusi subjek penelitian dapat dilihat pada Gambar 2. Distribusi terbanyak pada penelitian ini adalah anakberusia 13tahun(16 oranganakperempuan (20\%) dan 15 orang anak laki-laki $(18,75 \%)$ ) dan subjek yang paling sedikit berpartisipasi adalah anak yang berusia 18 tahun. 


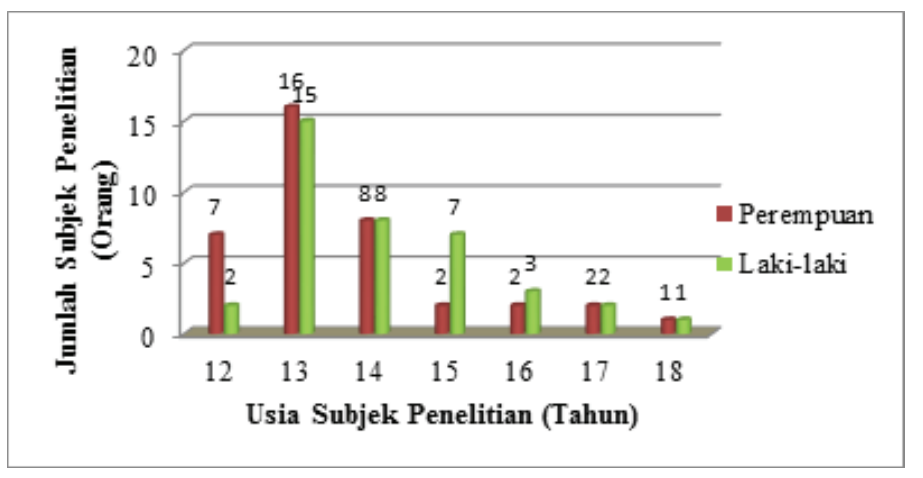

Gambar 2. Data distribusi Usia Subjek Penelitian

Hasil penelitian juga menggambarkan hubungan jenis kelamin terhadap tingkat kebersihan rongga dan mulut anak yang diukur melalui indek OHIS. Data penelitian ini menunjukkan rata-rata anak-anak panti asuhan memiliki tingkat kebersihan gigi dan mulut sedang $(1,3-3,0)$. Gambaran yang terlihat pada Tabel 1 ini menunjukkan anak perempuan memiliki nilai OHIS yang jauh lebih baik dari pada anak laki-laki. Anak perempuan menunjukkan OHIS baik sebanyak 9 orang $(23,7 \%)$, OHIS sedang sebanyak 23 orang $(60,5 \%)$ dan OHIS buruk sebanyak 6 orang (15,8\%). Sedangkan OHIS anak laki-laki menunjukkan hasil yang lebih buruk oleh karena terdapat 18 orang $(47,4 \%)$ dengan OHIS buruk dan hanya 2 orang $(5,3 \%)$ yang memiliki OHIS baik.

Nilai ini kemudian diuji menggunakan uji statistik dan diperoleh nilai $p$ value $(0,017)<$ 0,05 . Nilai $p$ ini menunjukkan ada perbedaan nilai kebersihan gigi (OHIS) antara anak perempuan dan anak laki-laki. Hubungan nilai kebersihan rongga mulut anak juga dapat diamati dari nilai chi square hitung yang diperoleh. Nilai chi square hitung penelitian ini lebih besar dibandingkan nilai chi square ${ }_{\text {tabel }}$ (chi square $_{\text {hitung }}(12,039)>$ chi square $\left._{\text {tabel }}(9,488)\right)$. Nilai ini menunjukkan Ho penelitian ditolak sehingga dapat disimpulkan ada hubungan kebersihan rongga mulut dengan jenis kelamin. (Tabel 1)

\section{DISKUSI}

Kebersihan gigi dan mulut sangat dipengaruhi oleh cara merawat gigi dan mulut yang dapat diukur menggunakan OHIS (oral hygiene index scores). Selain itu, penelitian ini juga menunjukkan ada perbedaan kebersihan gigi dan mulut anak perempuan dengan anak laki-laki. Kebersihan gigi dan mulut anak perempuan jauh lebih baik dibandingkan laki-laki (Tabel 1). Hasil penelitian ini sejalan dengan penelitian yang dilakukan oleh Zetu dan Ogunsile yang menyatakan OHIS anak perempuan lebih tinggi dibandingkan $\mathrm{OHIS}$ anak laki-laki ${ }^{5,6}$.

Tingginya nilai kebersihan gigi dan mulut diduga disebabkan oleh anak perempuan memiliki kecenderungan untuk lebih menjaga kesehatan gigi dan mulut mereka. Hal ini sesuai

Tabel 1. Hubungan Jenis Kelamin dengan Kebersihan Gigi (Oral Health IndexSimplified) Anak Panti Asuhan

\begin{tabular}{cc|c|c|c|c|c}
\multirow{2}{*}{ No } & Jenis Kelamin & $\mathrm{N}$ & \multicolumn{3}{|c|}{ Tingkat OHIS (orang (\%)) } & \multirow{2}{*}{$p$ Value } \\
\cline { 4 - 6 } & & Baik & Sedang & Buruk & \\
\hline 1 & Perempuan & 38 & 9 & $\begin{array}{c}23 \\
(60,5 \%)\end{array}$ & 6 \\
$(15,8 \%)$ & \multirow{2}{*}{0,017} \\
\hline 2 & Laki-laki & 38 & 2 & $\begin{array}{c}18 \\
(47,4 \%)\end{array}$ & $\begin{array}{c}18 \\
(47,4 \%)\end{array}$ & \\
\hline & $\mathrm{p}_{\text {hitung }}=12,039 ; \mathrm{p}_{\text {tabel }}$ & $=9,488$ dengan df adalah 4 &
\end{tabular}


dengan beberapa penelitian yang menyatakan bahwa perilaku menjaga kesehatan gigi dan mulut anak perempuan lebih baik dibandingkan anak laki-laki 5,6. Perilaku ini diduga dipengaruhi oleh perbedaan psikologis anak. Anak laki-laki diduga cenderung lebih tidak memperhatikan keadaan diri mereka sendiri termasuk kesehatan gigi dan mulut. Hal ini diduga adanya perbedaan kondisi gen dari anak perempuan dan laki-laki. Hal ini sesuai dengan penelitian Mirani yang menyatakan laki-laki sedikit lebih agresif dibandingkan wanita karena pada lakilaki terdapat gen SRY (Sex Determining Region Y) ${ }^{10}$. Gen ini diduga dapat menyebabkan anak laki-laki memiliki tingkat pengendalian emosi yang lebih rendah dibandingkan anak perempuan.

Perkembangan psikologis anak juga mempengaruhi kemampuan anak untuk menjaga kebersihan rongga mulut. Secara psikologis anak, usia subjek penelitian ini dapat digolongkan ke dalam usia remaja (Gambar 2). Pada usia ini, psikologis anak dapat dikelompokkan menjadi 3 (tiga) fase yaitu fase psikologi remaja awal/early adolescent (12-14 tahun), fase pertengahan/middle adolescent (15-17 tahun) dan fase akhir/late adolescent (18 tahun) ${ }^{11}$. Pada fase remaja ini terutama pada usia remaja awal dan pertengan sedang mengalami krisis identitas. Anak-anak usia ini cenderung lebih sering menunjukkan sikap perlawanan terhadap orang tua. Perlawanan ini diasumsikan mempengaruhi kualitas anak untuk menjaga kebersihan gigi dan mulut oleh karena orang tua sulit untuk mengarahkan anak-anak mereka untuk menjaga/melakukan tindakan preventif.

Usia ini juga mempengaruhi tingkat kedewasaan seseorang. Anak perempuan cenderung lebih cepat mengalami kedewasaan dibandingkan anak laki-laki ${ }^{12}$. Anak perempuan mencapai kedewasaan mulai dari usia 12 tahun sedangkan anak laki-laki sekitar usia 16 tahun. Kedewasaan ini juga diduga menjadi pemicu anak perempuan cenderung lebih cepat menjaga kesehatan gigi dan mulut mereka dibandingkan anak laki-laki. Selain itu, anak perempuan diduga lebih cepat merasa malu dan memiliki ketertarikan dengan lawan jenis sehingga mereka lebih mengupayakan untuk tampil cantik dan bersih untuk memikat lawan jenis mereka. Mereka mengupayakan untuk selalu menyikat gigi semampu mereka sehingga mempermudah interaksi dengan lingkungan. Anak perempuan saat usia ini juga cenderung lebih memiliki rasa malu yang lebih tinggi dibanding laki-laki. Dugaan ini sejalan dengan penelitian yang dilakukan oleh Zetu yang menyatakan perempuan lebih memiliki perilaku positif terhadap kebersihan gigi dan mulut serta memiliki kepercayaan diri tinggi untuk meningkatkan kebersihan gigi dan mulut mereka ${ }^{5}$. Saat penelitian ini dilakukan anak perempuan lebih kooperatif dan menerima masukan yang diajarkan / dianjurkan walaupun menunjukkan rasa cemas saat diberikan intruksi oleh peneliti.

Perbedaan kebersihan gigi dan mulutanak ini juga dipengaruhi oleh tingkat kecemasan terhadap perawatan gigi. Anak perempuan cenderung memiliki tingkat kecemasan yang jauh lebih tinggi dibandingkan dengan anak laki-laki. Pernyataan ini sesuai dengan penelitian yang dilakukan oleh Farooq yang menyatakan ada perbedaan tingkat kecemasan anak perempuan pada mahasiswa pre klinik kedokteran gigi jauh lebih tinggi dibandingkan anak laki-laki ${ }^{13}$. Tingkat kecemasan yang tinggi ini menyebabkan anak perempuan lebih berusaha menguramgi rasa takutnya dengan mencari dan melakukan tindakan preventif dan kuratif yang dianjurkan oleh praktisi kesehatan dibandingkan anak laki-laki. Kondisi ini menyebabkan OHIS anak perempuan lebih baik dibandingkan anak laki-laki.

Penelitian ini berbeda dengan penelitian yang dihasilkan oleh Indrawati. Hal ini mungkin disebabkan adanya perbedaan usia gender yang di ambil. Pada penelitian ini, usia gender yang dipilih adalah anak yang berusia 12-18 tahun sedangkan pada penelitian Indrawati, usia gender yang digunakan sangat variatif (sebaran usia sangat luas usia kurang 35 tahun sampai lebih dari 35 tahun) ${ }^{8}$. Usia 35 tahun kecenderungan mereka untuk menjaga gigi dan mulut jauh lebih baik dan berpengalaman dibandingkan anak usia remaja. Selain itu, usia dewasa sudah menjadi contoh bagi anak-anak 
mereka untuk menjaga kebersihan gigi dan mulut sehingga mereka mengupayakan untuk selalu menjadi panutan anak.

Ketidakhadiran orang tua dalam hal ini orang yang dewasa diduga menyebabkan anak lebih kurang termotivasi untuk menjaga kesehatan gigi dan mulut mereka. Subjek penelitian ini secara keseluruhan adalah anakanak yang diasramakan dalam wadah panti asuhan yang dimodifikasi dengan pasantren modern, anak-anak ini mencari perhatian lebih kepada pendamping mereka karena tidak memiliki orang tua secara lengkap. Kondisi ini menyebabkan anak meniru dan menduplikasi tindakan kebersihan gigi dalam lingkungan mereka. Hal ini sesuai dengan penelitian yang dilakukan oleh Saeid yang menyatakan kebersihan gigi dan mulut anak sangat dipengaruhi oleh kehadiran orang tua terutama kehadiran seorang ibu ${ }^{9}$. Pola asuh anak yang diasramakan dan masa lalu mereka juga mempengaruhi kebersihan gigi dan mulut mereka. Pola asuh anak asrama jauh dari kehangatan orang tua, anak bebas mengekspresikan keinginan mereka dan bertanggung jawab terhadap keputusan mereka masing-masing. Pola ini akan membentuk anak memiliki kepercayaan diri yang tinggi, bertanggung jawab dan mampu mengontrol diri 14. Pola asuh ini menyebabkan rata-rata indeks kebersihan gigi dan mulut anak paling banyak di kategori sedang (Tabel 1).

\section{KESIMPULAN}

Ada hubungan jenis kelamin dengan kebersihan gigi dan mulut anak dimana anak perempuan memiliki indek kebersihan gigi dan mulut yang lebih baik dibandingkan kebersihan gigi dan mulut anak laki-laki. Penelitian ini juga belum menggambarkan pengaruh usia dan psikologis terhadap kebersihan gigi dan mulut anak. Oleh karena itu, perlu dilakukan penelitian lanjutan yang lebih mendalam terutama yang berhubungan dengan usia dan psikologis anak terhadap kebersihan gigi dan mulut.

\section{UCAPAN TERIMAKASIH}

Ucapan terima kasih ditujukan kepada kepala dan anak panti asuhan al Ishlah Al Aziziyah yang telah membantu penelitian ini. Ucapan terimakasih juga kami tujukan kepada Direktorat Jenderal Pendidikan Tinggi Kementerian Pendidikan dan Kebudayaan yang telah membiayai penelitian ini sesuai dengan perjanjian penugasaan dalam rangka pelaksanaan kegiatan program pengabdian masyarakat tahun anggaran 2014.

\section{DAFTAR PUSTAKA}

1. Unicef. Konveksi hak hak anak. www. Unicef.org/../ CRC_bahasa Indonesia/ (30 Maret 2015)

2. Hidayat, Aziz A. Pengantar ilmu keperawatan anak I. Jakarta: Salemba Medika;2005

3. Riset Kesehatan Dasar. Laporan hasil riset kesehatan dasar nasional: Depkes, 2013. 2008 130-37

4. Anitasari S, Rahayu NE. Hubungan frekuensi menyikat gigi dengan tingkat kebersihan gigi dan mulut siswa sekolah dasar, Dent J 2005;38(2):88-90

5. Zetu I, Zetu L, Dogaru CB, Duta C, Dumitrescu AL. Gender variations in psychological factor as defined by the theory of planned of oral hygiene behaviors. J Procedia-Soc and Behav Sci, 2014;127:353-7

6. Ogunsile SE, Ojo L. Oral hygiene status of adolescents in a local government area of Oyo state Nigeria, $\mathrm{J}$ of Sci and Tech 2010;30(3):81-6

7. Mutawa SA, ShyamaM, Duwairi Y, Soparkar P. Oral hygiene status of Kuwaiti school children, EMHJ 2011;17(5):387-91

8. Indrawati TN, Lannywati G. Status dan kesehatan gigi dan mulut ditinjau dari faktor individu pengunjung puskesmas DKI Jakarta tahun 2007, Buletin Penelitian Kesehatan 2010;38(2):179-87

9. Saied MZ, Virtanen JL, Ghofranipour F, Murtomaa $\mathrm{H}$. Influence of mother oral health knowledge and attitude on their children's dental health, Eur Archv of Paed Dent 2008;2(9):16-68

10. Mirani E. Pengaruh konseling genetik pada tingkat kecemasan dan depresi terhadap gender ambigus genitalia. Thesis. Semarang: Universitas Diponegoro, 2009

11. Christie D, Viner D. $A B C$ of adolescent: adolescent development, BMJ 2005;30;30:1-4

12. Batubara JRL. Adolescent development (perkembangan remaja). sari pediatric 2010: 12(1):21-9

13. Farooq I, Ali S. A cross sectional study of gender differences in dental Anxiety prevailing in the students 
of a Pakistani dental collage. The Saudi J of dent research 2015;6:21-5

14. Galib N, Yusuf H. Pengaruh pola asuh orang tua terhadap tingkat kooperatif anak usia 3-5 tahun dalam perawatan gigi dan mulut. Proceeding pertemuan ilmiah nasional ilmu kedokteran gigi anak VII; Medan, 2015: 45-9 